izv. prof. dr. sc. Hrvoje Perčević

Ekonomski fakultet, Sveučilište u Zagrebu, Zagreb, Republika Hrvatska hpercevic@efzg.hr

Marina Mićin, mag. oec.

Ekonomski fakultet, Sveučilište u Zagrebu, Zagreb, Republika Hrvatska mmicin@efzg.hr

\title{
POVEZANOST KRETANJA NETO IMOVINE INVESTICIJSKIH FONDOVA I BRUTO DOMAĆEG PROIZVODA U REPUBLICI HRVATSKOJ
}

Pregledni rad

\section{Sažetak}

Investicijski fondovi postaju sve značajniji sudionik na tržištu kapitala u Republici Hrvatskoj, odnosno investitori sve više koriste investicijske fondove kao jednu od mogućnosti investiranja viška novčanih sredstava. Temeljni cilj ulaganja u dionice $i$ udjele investicijskih fondova jest ostvarivanje zadovoljavajućeg povrata na investirana sredstva $s$ obzirom na anticipirani rizik ulaganja. Ulaganje $u$ dionice $i$ udjele investicijskih fondova predstavlja vrlo zanimljiv oblik ulaganja $i$ to posebno tzv. malim investitorima budući da velik broj tzv. malih investitora nema dovoljno relevantnog znanja i iskustva iz područja investicijske analize $i$ tržišta kapitala te temeljem toga ne mogu formirati investicijski portfelj kojim će disperzirati rizik ulaganja. S obzirom da menadžeri investicijskih fondova formiraju portfelj vrijednosnih papira po principu diverzifikacije, ulaganjem u dionice i udjele investicijskih fondova mali investitori indirektno disperziraju rizik ulaganja. Na taj se način malim investitorima koji potencijalno nemaju dovoljno znanja i iskustva da sami pristupe tržištu kapitala omogućava da sudjeluju na tržištu kapitala preko onih koji posjeduju znanje $i$ mogućnosti. Cijena udjela $u$ fondu, odnosno, neto imovina fonda se računa na dnevnoj razini i ovisi o kretanjima cijena vrijednosnih papira koji su uvršteni u portfelj fonda. Cijene dionica na tržištu kapitala su povezane s kretanjem bruto domaćeg proizvoda (BDP), odnosno kada je na razini države gospodarska situacija povoljna, raste BDP ali rastu i cijene dionica. Drugim riječima, rast gospodarstva pojedine zemlje utječe na rast BDP-a ali i na rast tržišnih cijena vrijednosnih papira. Posljedično rast tržišnih cijena vrijednosnih papira utječe na rast neto imovine investicijskih fondova, ali i obrnuto. Temeljni cilj ovog rada je istražiti jesu li kretanja neto imovine investicijskih fondova usklađena s kretanjima BDP-a, odnosno postoji li povezanost između tih dviju varijabli. U radu će se analizirati kretanja vrijednosti neto imovine investicijskih fondova i BDP-a na području Republike Hrvatske.

Ključne riječi: investicijski fondovi, neto imovina, bruto domaći proizvod, Republika Hrvatska

JEL: M41 


\section{UVOD}

U suvremenim razvijenim tržištima kapitala investicijski fondovi predstavljaju jednog od najznačajnijih institucionalnih investitora i pokazatelj su stupnja razvijenosti financijskog sustava. Što je financijski sustav određene zemlje razvijeniji, veći je broj različitih investicijskih fondova i ostalih financijskih institucija koje nemaju karakter kreditnih institucija odnosno čiji predmet poslovanja ne uključuje kreditno-depozitne poslove. U znanstvenoj i stručnoj literaturi velik broj autora bavio se odnosom razvijenosti nacionalne ekonomije i financijskog sustava, pri čemu su rezultati tih istraživanja pokazivali da postoji značajna povezanost između razvijenosti nacionalne ekonomije i njezinog financijskog sustava odnosno što je viši stupanj razvijenosti nacionalne ekonomije, razvijeniji je i njezin financijski sustav. Općenito, financijski sustav pojedine zemlje sastoji se od tri temeljna konstitutivna elementa, a to su financijska tržišta, financijske institucije i financijski instrumenti. Pojedini autori ovim trima konstitutivnim elementima financijskog sustava dodaju i četvrti, a to je pravna regulativa financijskog sustava (Babić, str. 347.). Temeljna svrha financijskog sustava sastoji se u kanaliziranju financijskih sredstava novčano suficitarnih subjekata prema novčano deficitarnim subjektima. U tom procesu jednu od ključnih uloga imaju financijske institucije koje prikupljaju novčana sredstva od novčano suficitarnih subjekata, najčešće emisijom svojih financijskih instrumenata, i usmjeravaju ih prema novčano deficitarnim subjektima investiranjem prethodno prikupljenih novčanih sredstava u financijske instrumente koje emitiraju novčano deficitarni subjekti. Razvijenost financijskog sustava pojedine zemlje utvrđuje se postojanjem različitih oblika financijskog tržišta, velikim brojem različitih financijskih institucija te postojanjem većeg broja različitih vrsta financijskih instrumenata koji kotiraju na financijskim tržištima. Razvijene zemlje odlikuju se razvijenim financijskim sektorom koji podrazumijeva razvijenost financijskog tržišta, postojanje velikog broja različitih vrsta financijskih institucija pri čemu dominiraju tzv. nedepozitne financijske institucije te prisutnost različitih vrsta financijskih instrumenata koji kotiraju na financijskom tržištu. Financijske institucije kao konstitutivni element financijskog tržišta smatraju se financijskim posrednicima (intermedijarima) koji pospješuju transfer novčanih sredstava od novčano suficitarnih subjekata prema novčano deficitarnim subjektima što u konačnici dovodi do većeg bruto društvenog proizvoda. U razvijenim zemljama s razvijenim financijskim sustavom kao financijski posrednici dominiraju nedepozitne financijske institucije, među kojima su jedni od najznačajnijih investicijski fondovi. Atraktivnost investicijskih fondova kao investicijske mogućnosti proizlazi iz postojanja širokog spektra različitih vrsta investicijskih fondova koji se prilagođavaju profilima različitih investitora. Investicijski fondovi su u mogućnosti prikupiti akumuliranu štednju od širokog broja različitih investitora, kako od tzv. malih investitora s malim iznosom ulaganja do poslovnih subjekata s velikim raspoloživim iznosom ulaganja. 
Upravo zbog toga se oni smatraju jednim od najefikasnijih financijskih posrednika na financijskom tržištu.

U nerazvijenim zemljama i zemljama u razvoju financijski sustav je na nižem stupnju razvoja u odnosu na razvijene zemlje i uglavnom ga karakterizira nerazvijenost ili slaba razvijenost financijskog tržišta, postojanja samo osnovnih financijskih instrumenata koji kotiraju na financijskom tržištu te dominacija depozitnih financijskih institucija i to prvenstveno kreditnih institucija. U zemljama sa slabo razvijenim financijskim sustavom, značajnost investicijskih fondova kao financijskih posrednika na financijskom tržištu nije ni približno tolika kao u razvijenim zemljama s razvijenim financijskim sustavom. Investitori koji djeluju u slabo razvijenom financijskom sustavu imaju znatno manje mogućnosti ulaganja nego investitori koji djeluju u razvijenom financijskom sustavu. Slabo razvijeni financijski sustav ne doprinosi efikasnom transferu novčanih sredstava od novčano suficitarnih subjekata prema novčano deficitarnim subjektima čime zapravo ne doprinosi povećanju bruto društvenog proizvoda zemlje.

Svrha ovog rada sastoji se u utvrđivanju postojanja povezanosti između kretanja bruto društvenog proizvoda i kretanja neto imovine investicijskih fondova. Investicijski fondovi prikupljaju akumuliranu štednju novčano suficitarnih subjekata emisijom ,svojih“ udjela odnosno dionica i plasiraju ih u financijske instrumente koje emitiraju novčano deficitarni subjekti formirajući portfelj koji djeluju po principu diverzifikacije rizika a u skladu s prethodno definiranom investicijskom strategijom i ciljevima investicijskog fonda te njihovom nacionalnom zakonskom regulativom. S obzirom da se imovina tj. portfelj investicijskih fondova sastoji pretežno od financijskih instrumenata, vrijednost neto imovine investicijskih fondova ovisi o kretanjima tržišnih cijena financijskih instrumenata i ostale imovine u portfelju investicijskog fonda. Razvijenost nacionalne ekonomije doprinosi povećanju tržišnih cijena financijskih instrumenata što izravno utječe na rast vrijednosti neto imovine investicijskih fondova. Stoga je u ovom radu postavljena hipoteza prema kojoj postoji pozitivna povezanost između kretanja bruto društvenog proizvoda i vrijednosti neto imovine investicijskih fondova. Hipoteza će se testirati na temelju podataka o kretanju bruto društvenog proizvoda i vrijednosti neto imovine investicijskih fondova u Republici Hrvatskoj.

\section{PREGLED LITERATURE}

\subsection{Značajnost investicijskih fondova kao financijskih posrednika na tržištu kapitala i njihov utjecaj na ekonomski rast}

Investicijski fondovi djeluju kao jedan od najznačajnijih financijskih posrednika na tržištu kapitala. Naravno da je njihova značajnost i učinkovitost kao sudionika 
na tržištu kapitala značajnija i izraženija u zemljama s razvijenim financijskim sustavom odnosno razvijenim tržištima kapitala, dok u tzv. zemljama u razvoju značajnost investicijskih fondova nije toliko izražena kao u razvijenim zemljama. Razlog tome jest i slabo razvijeni financijski sustav zemalja u razvoju kao i slabija razvijenost nacionalne ekonomije. Značajnost investicijskih fondova kao financijskih posrednika na tržištu kapitala raste u tzv. tranzicijskim zemljama usporedno s rastom nacionalne ekonomije te daljnjom implementacijom i razvojem principa tržišne ekonomije u pojedinim tranzicijskim zemljama.

Investicijski fondovi smatraju se pokretačem i jednim od najznačajnijih indikatora razvijenosti tržišta kapitala (Gulin, str. 129). U nacionalnim ekonomijama s visoko razvijenim tržištem kapitala investicijski fondovi su jedna od najdominantnijih financijskih institucija na tržištu kapitala koji mogu snažno utjecati na cijenu kapitala te na ekonomski rast pojedine regije kao i, u suvremenim globalizacijskim uvjetima, na ekonomski rast cijele svjetske ekonomije (Gulin, str. 129.). Kao financijski posrednici koji usmjeravaju novčana sredstva novčano suficitarnih subjekata prema novčano deficitarnim subjektima, oni djeluju i na primarnom i na sekundarnom tržištu kapitala. Na primarnom tržištu uloga investicijskih fondova sastoji se u prikupljanju novčanih sredstava novčano suficitarnih subjekata putem emisije udjela ili dionica putem javne ili privatne ponude. Novčana sredstva prikupljena emisijom udjela ili dionica na primarnom tržištu kapitala, investicijski fondovi ulažu u financijske instrumente na sekundarnom tržištu kapitala ili u drugu imovinu (npr. nekretnine) u skladu s prospektom, strategijom i ciljevima investicijskog fonda. Djelovanje investicijskih fondova kao financijskih posrednika na tržištu kapitala prikazano je na slici 1.

Slika 1. Djelovanje investicijskih fondova kao financijskih posrednika na tržištu kapitala

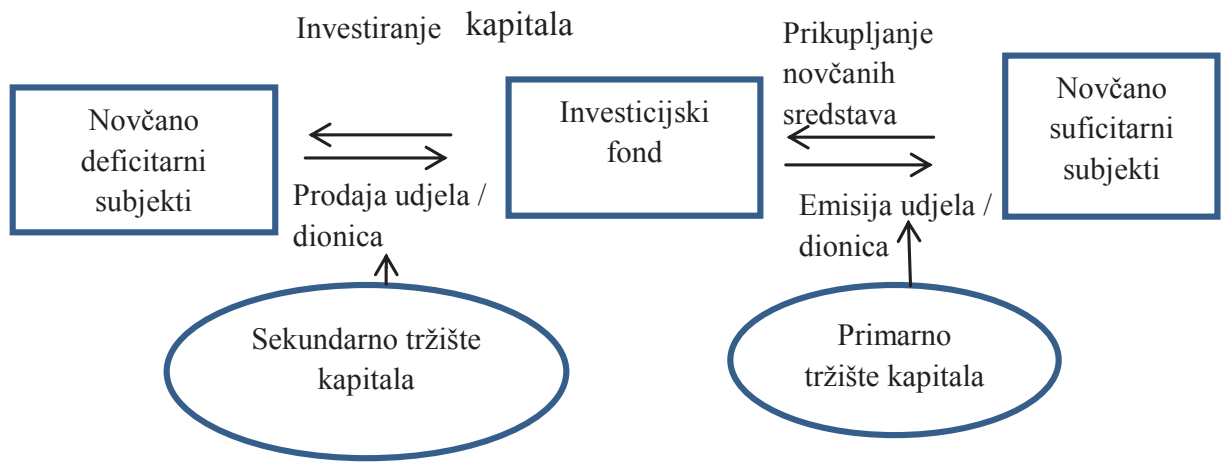

Izvor: Brealey, R. A., Myers, S. C., Marcus, A. J.: Fundamentals of Corporate Finance, New York, McGraw Hill Irwin, 2004., str. 32. 
Investicijski fondovi uobičajeno formiraju portfelj ulažući u različite financijske instrumente odnosno financijske instrumente s različitim prinosom i rizikom čime se postiže optimizacija rizika. Veća razina disperzije portfelja investicijskog fonda omogućava veću razinu disperzije rizika. Osim toga, investicijskim fondom upravlja profesionalni menadžment čiji je temeljni cilj formiranje portfelja ulaganjem u financijske instrumente (ili drugu imovinu) s iznadprosječnim prinosom u svrhu osiguranja što veće uspješnosti investicijskog fonda (Brealey, Myers, Marcus, str. 32.). Investicijski fondovi imaju veću mogućnost prikupljanja disperzirane štednje novčano suficitarnih subjekata od klasičnih depozitno-kreditnih financijskih institucija, budući su njihovi udjeli odnosno dionice prilagođene različitim kategorijama investitora, a osim toga oni pružaju investitorima niske troškove diverzifikacije te uslugu profesionalnog menadžmenta. Za mnoge investitore (posebno tzv. male investitore s nedovoljnim poznavanjem investicijske analize i financijskog tržišta) mnogo je efikasnije ulagati u udjele i dionice investicijskih fondova nego formirati vlastiti porfelj s različitim financijskim instrumentima (Brealey, Myers, Marcus, str. 31.), budući da na taj način optimiziraju prinos i rizik ulaganja na prihvatljivu razinu sukladno svojim financijskim mogućnostima. Fond menadžeri pružaju investitorima u udjele i dionice investicijskih fondova uslugu optimizacije povrata i rizika ulaganja, a za svoje usluge uzimaju menadžersku naknadu koja se uobičajeno u SAD-u kreće do $2 \%$ (Brealey, Myers, Marcus, str. 32) a u UK od 0,5\% do 1\% vrijednosti neto imovine investicijskog fonda (Pilbeam, str. 48.).

Ulaganje u investicijske fondove je bilo vrlo intenzivno u vrijeme ekonomskog rasta tijekom 80-tih i 90-tih godina 20. stoljeća (Pilbeam, str. 48.), dok je tijekom recentne financijske krize u 2007. godini njihova popularnost kao investicijske mogućnosti rapidno pala. Međutim, oporavak od financijske krize koji je započeo u Sad-u i UK, ponovno je intenzivirao interes investitora za ulaganje u udjele i dionice investicijskih fondova. Iako je financijska kriza iz 2007. godine utjecala na efikasnost investicijskih fondova i uzrokovala slom određenog broja investicijskih fondova, njihova značajnost kao jednog od ključnih ,igrača“" na tržištu kapitala održala se usprkos financijskoj krizi. U SAD-u kao jednoj od najrazvijenijih i najznačajnijih svjetskih ekonomija s izuzetno razvijenim financijskim sustavom broj investicijskih fondova je kontinuirano rastao od 1940. godine do početka 2000-tih tijekom kojih se njihov broj ustalio da bi tijekom financijske krize 2007. i 2008. njihov broj se lagano smanjio. Međutim, već od 2011. godine ponovno se bilježi rast broja investicijskih fondova kako se SAD oporavljaju od financijske krize. Kretanje broja investicijskih fondova kao i vrijednosti njihove neto imovine u SAD-u od 1940. godine do 2013. godine prikazan je na slici 2. 
Slika 2. Kretanje broja investicijskih fondova i vrijednosti njihove neto imovine u SAD-u u razdoblju od 1940. do 2013.

\section{TABLE 1 \\ Total Net Assets, Number of Funds, Number of Share Classes, and Number of \\ Shareholder Accounts of the Mutual Fund Industry}

\section{Year-end}

\begin{tabular}{|c|c|c|c|c|}
\hline Year & $\begin{array}{l}\text { Total net assets } \\
\text { Bifions of dollars }\end{array}$ & Mumber of funds & $\begin{array}{l}\text { Number of } \\
\text { share classes }\end{array}$ & $\begin{array}{c}\text { Mumber of shareholder accounts* } \\
\text { Thousands }\end{array}$ \\
\hline 1940 & $\$ 0.45$ & 68 & - & 296 \\
\hline 1945 & 2.28 & 73 & - & 498 \\
\hline 1950 & 2.53 & 98 & - & 939 \\
\hline 1955 & 784 & 125 & - & 2.085 \\
\hline 1960 & 17.03 & 161 & - & 4,898 \\
\hline 1965 & 35.22 & 170 & - & 6,709 \\
\hline 1970 & 47.62 & 361 & - & 10,690 \\
\hline 1975 & 45.87 & 426 & - & 9.876 \\
\hline 1976 & 51.28 & 452 & - & 9,060 \\
\hline 1977 & 48.94 & 477 & - & 8,693 \\
\hline 1978 & 55.84 & 505 & - & 8,658 \\
\hline 1979 & 94.51 & 526 & - & 9.790 \\
\hline 1980 & 134.76 & 564 & - & 12,088 \\
\hline 1981 & 24137 & 665 & - & 17.499 \\
\hline 1982 & 296.68 & 857 & - & 21,448 \\
\hline 1983 & 29299 & 1.026 & - & 24,605 \\
\hline 1984 & 370.68 & 1.243 & 1.243 & 27,636 \\
\hline 1985 & 495.39 & 1.528 & $1,52 \mathrm{~B}$ & 34,098 \\
\hline 1986 & 715.67 & 1.835 & 1.855 & 45,374 \\
\hline 1987 & 769.17 & 2.312 & 2,312 & 53,717 \\
\hline $198 B$ & 809.37 & 2,737 & 2,737 & 54,056 \\
\hline 1989 & 990.67 & 2.955 & 2.955 & 57.560 \\
\hline 1990 & $1,065.19$ & 3,079 & 3,177 & 61,948 \\
\hline 1991 & $1,393.19$ & 3.403 & 3,587 & 68,332 \\
\hline 1992 & 1,64254 & 3,8224 & 4,208 & 79,931 \\
\hline 1993 & 2.069 .96 & 4.534 & 5,562 & 94,015 \\
\hline 1994 & 2,15532 & 5,325 & 7,697 & 114,383 \\
\hline 1995 & 2.81129 & 5.725 & 9,007 & 131.219 \\
\hline 1996 & $3,525.80$ & 6.248 & 10,352 & 149,933 \\
\hline 1997 & 4.468 .70 & 6.684 & 12,002 & 170.299 \\
\hline 1998 & $5,525.21$ & 7,314 & 13,720 & 194,029 \\
\hline 1999 & 6.84634 & 7.791 & 15,262 & 226,212 \\
\hline 2000 & $6,964.63$ & 8.155 & 16,738 & 244,705 \\
\hline 2001 & $6,974.91$ & 8.305 & 18,022 & 248,701 \\
\hline 2002 & $6,383,48$ & 8,243 & 18,983 & 251,123 \\
\hline 2003 & 7.402 .42 & 8.125 & 19,317 & 260.698 \\
\hline 2004 & 8.095 .45 & 8.042 & 20.035 & 269,468 \\
\hline 2005 & 8.891 .11 & 7,974 & 20.548 & 275,479 \\
\hline 2005 & $10,397.88$ & 8,117 & 21,249 & 288,594 \\
\hline 2007 & 11.999 .73 & 8.023 & 21,610 & 292.553 \\
\hline 2008 & 9.602 .57 & 8,019 & 22.252 & 264,597 \\
\hline 2009 & $11,112.67$ & 7,659 & 21,661 & 269,449 \\
\hline 2010 & 11.83133 & 7,548 & 21,907 & 291,299 \\
\hline 2011 & 11.626 .49 & 7,580 & 22,249 & 272,628 \\
\hline 2012 & 13.043 .67 & 7,582 & 22,605 & 257.074 \\
\hline 2013 & 15.017 .68 & 7.707 & 23,353 & 264,848 \\
\hline
\end{tabular}

Izvor: Investment Company Fact Book 2014., dostupno na: https:/www.quora.com/

What-is-the-total-number-of-mutual-funds-in-the-US, pristupljeno 28.06.2017. 
U današnjem poslovnom okruženju tržišta kapitala su u većoj mjeri globalizirana čime je uloga investicijskih fondova kao financijskih posrednika još više dobila na značaju. Velik broj investicijskih fondova djeluje na globalnom tržištu kapitala preko kojeg im se omogućava pristup regionalnim i lokalnim tržištima kapitala. $\mathrm{Na}$ taj način investicijski fondovi mogu pospješiti ekonomski rast pojedinih nacionalnih ekonomija ulažući u financijske instrumente njihovih poslovnih subjekata s ciljem ostvarivanja zadovoljavajuće razine prinosa za vlasnike. $U$ današnjim uvjetima globaliziranog tržišta kapitala posebno su značajni oni investicijski fondovi koji primarno djeluju na razvijenim zemljama s razvijenim financijskim tržištem. Prema podacima Instituta investicijskih kompanija (Investment Company Institute), na kraju 2014. godine na svijetu je djelovalo preko 79.000 investicijskih fondova (Investment Company Institute). Raspored investicijskih fondova po pojedinim zemljama prikazan je na slici 3 .

Slika 3. Broj investicijskih fondova po pojedinim zemljama na kraju 2014. godine

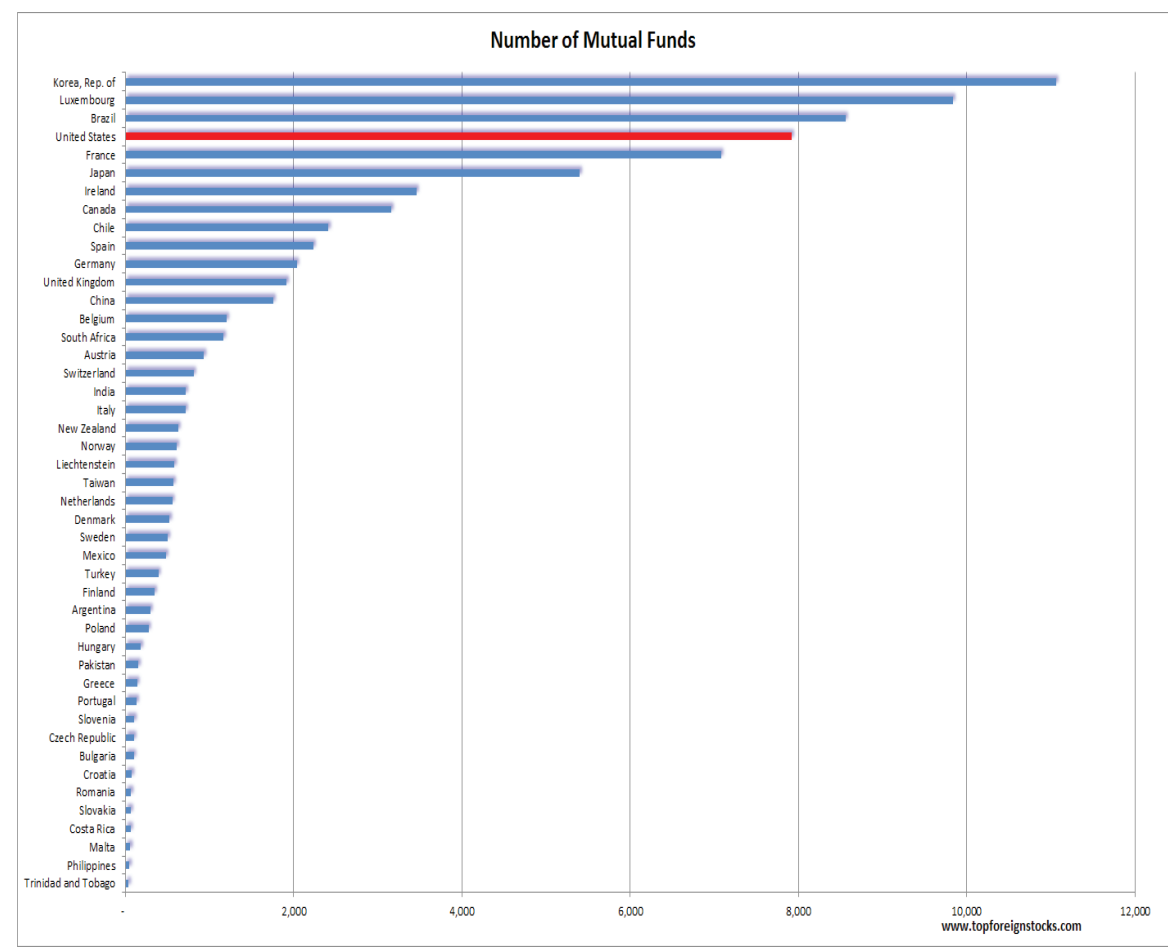

Izvor: http://topforeignstocks.com/2016/04/14/number-of-mutual-funds-by-country/, pristupljeno 28.06.2017. Konkretnija i detaljnija analiza o kretanju broju investicijskih fondova po pojedinim zemljama i kontinentima u razdoblju od 2007. do 2014. godine dana je u tablici 1. 
Tablica 1. Kretanje broja investicijskih fondova po kontinentima i pojedinim zemljama u razdoblju od 2007. do 2014. godine

\begin{tabular}{|c|c|c|c|c|c|c|c|c|}
\hline & 2007 & 2008 & 2009 & 2010 & 2011 & 2012 & 2013 & 2014 \\
\hline World & 66.362 & 69.049 & 67.533 & 69.492 & 72.607 & 73.235 & 76.206 & 79.669 \\
\hline Americas & 15.474 & 16.476 & 16.935 & 17.992 & 19.749 & 21.095 & 22.026 & 22.962 \\
\hline Argentina & 241 & 253 & 252 & 254 & 281 & 291 & 297 & 302 \\
\hline Brazil & 3.381 & 4.169 & 4.744 & 5.618 & 6.513 & 7.468 & 8.072 & 8.560 \\
\hline Canada & 2.038 & 2.015 & 2.075 & 2.117 & 2.655 & 2.866 & 2.963 & 3.164 \\
\hline Chile & 1.260 & 1.484 & 1.691 & 1.912 & 2.150 & 2.286 & 2.385 & 2.418 \\
\hline Costa Rica & 93 & 85 & 64 & 68 & 63 & 66 & 66 & 66 \\
\hline Mexico & 420 & 431 & 407 & 434 & 464 & 488 & 487 & 486 \\
\hline Trinidad and Tobago & N/A & N/A & 36 & 35 & 36 & 42 & 43 & 43 \\
\hline United States & 8.041 & 8.039 & 7.666 & 7.554 & 7.587 & 7.588 & 7.713 & 7.923 \\
\hline Europe & 35.210 & 36.780 & 34.899 & 35.292 & 35.713 & 34.470 & 34.743 & 35.163 \\
\hline Austria & 1.070 & 1.065 & 1.016 & 1.016 & 1.003 & 995 & 981 & 938 \\
\hline Belgium & 1.655 & 1.828 & 1.845 & 1.797 & 1.723 & 1.529 & 1.432 & 1.209 \\
\hline Bulgaria & N/A & 81 & 85 & 90 & 92 & 95 & 98 & 103 \\
\hline Croatia & N/A & N/A & N/A & N/A & N/A & N/A & $\mathrm{N} / \mathrm{A}$ & 82 \\
\hline Czech Republic & 66 & 76 & 78 & 80 & 80 & 80 & 85 & 106 \\
\hline Denmark & 500 & 489 & 483 & 490 & 500 & 495 & 510 & 530 \\
\hline Finland & 379 & 389 & 377 & 366 & 368 & 375 & 369 & 352 \\
\hline France & 8.243 & 8.301 & 7.982 & 7.791 & 7.744 & 7.392 & 7.154 & 7.082 \\
\hline Germany & 1.462 & 1.675 & 2.067 & 2.106 & 2.051 & 2.059 & 2.012 & 2.039 \\
\hline Greece & 230 & 239 & 210 & 213 & 196 & 177 & 166 & 143 \\
\hline Hungary & 212 & 270 & 264 & 276 & 152 & 167 & 182 & 189 \\
\hline Ireland & 2.898 & 3.097 & 2.721 & 2.899 & 3.085 & 3.167 & 3.345 & 3.462 \\
\hline Italy & 924 & 742 & 675 & 650 & 659 & 600 & 661 & 719 \\
\hline Liechtenstein & 391 & 335 & 348 & 409 & 437 & 535 & 657 & 587 \\
\hline Luxembourg & 8.782 & 9.351 & 9.017 & 9.353 & 9.462 & 9.435 & 9.500 & 9.839 \\
\hline Malta & $\mathrm{N} / \mathrm{A}$ & $\mathrm{N} / \mathrm{A}$ & $\mathrm{N} / \mathrm{A}$ & N/A & 59 & 54 & 69 & 63 \\
\hline Netherlands & 450 & $458^{a}$ & N/A & $\mathrm{N} / \mathrm{A}$ & 495 & 497 & 501 & 561 \\
\hline Norway & 511 & 530 & 487 & 507 & 507 & 406 & 573 & 616 \\
\hline Poland & 188 & 210 & 208 & 214 & 226 & 259 & 264 & 278 \\
\hline Portugal & 180 & 184 & 171 & 171 & 173 & 157 & 153 & 137 \\
\hline Romania & 41 & 52 & 51 & 56 & 105 & 62 & 64 & 72 \\
\hline Russia & 533 & 528 & 480 & 462 & 472 & $\mathrm{~N} / \mathrm{A}$ & $\mathrm{N} / \mathrm{A}$ & $\mathrm{N} / \mathrm{A}$ \\
\hline Slovakia & 54 & 56 & 54 & 58 & 63 & 58 & 54 & 67 \\
\hline Slovenia & 106 & 125 & 125 & 130 & 137 & 131 & 114 & 111 \\
\hline Spain & 2.940 & 2.944 & 2.588 & 2.486 & 2.474 & 2.349 & 2.267 & 2.238 \\
\hline Sweden & 477 & 508 & 506 & 504 & 508 & 456 & 484 & 510 \\
\hline Switzerland & 567 & 572 & 509 & 653 & 664 & 667 & 765 & 815 \\
\hline Turkey & 294 & 304 & 286 & 311 & 337 & 351 & 373 & 395 \\
\hline United Kingdom & 2.057 & 2.371 & 2.266 & 2.204 & 1.941 & 1.922 & 1.910 & 1.920 \\
\hline Asia and Pacific & 14.847 & 14.909 & 14.795 & 15.265 & 16.198 & 16.703 & 18.375 & 20.373 \\
\hline Australia & N/A & $\mathrm{N} / \mathrm{A}$ & N/A & $\mathrm{N} / \mathrm{A}$ & N/A & N/A & $\mathrm{N} / \mathrm{A}$ & N/A \\
\hline China & 341 & 429 & 547 & 660 & 831 & 1.065 & 1.415 & 1.763 \\
\hline Hong Kong & 1.162 & N/A & $\mathrm{N} / \mathrm{A}$ & N/A & N/A & N/A & N/A & N/A \\
\hline India & 555 & 551 & 590 & 658 & 680 & 692 & 699 & 723 \\
\hline Japan & 2.997 & 3.333 & 3.656 & 3.905 & 4.196 & 4.384 & 4.922 & 5.404 \\
\hline Korea, Rep. of & 8.609 & 9.384 & 8.703 & 8.687 & 9.064 & 9.121 & 9.876 & 11.063 \\
\hline New Zealand & 623 & 643 & 702 & 700 & 709 & 700 & 694 & 632 \\
\hline Pakistan & 64 & 83 & 96 & 125 & 137 & 139 & 152 & 159 \\
\hline Philippines & 40 & 43 & 41 & 43 & 47 & 48 & 47 & 52 \\
\hline Taiwan & 456 & 443 & 460 & 487 & 534 & 554 & 570 & 577 \\
\hline Africa & 831 & 884 & 904 & 943 & 947 & 967 & 1.062 & 1.171 \\
\hline South Africa & 831 & 884 & 904 & 943 & 947 & 967 & 1.062 & 1.171 \\
\hline
\end{tabular}

Izvor: http:/topforeignstocks.com/2016/04/14/number-of-mutual-funds-by-country/, pristupljeno 28.06 .2017 .

Kao što se može vidjeti iz tablice 1. u razdoblju od 2007. do 2014. godine broj investicijskih fondova je na svjetskoj razini rastao usprkos globalnoj financijskoj 
krizi. Pri tome, najveći broj investicijskih fondova je u europskim zemljama, nakon toga slijede američke zemlje te azijske i pacifičke zemlje, dok je najmanji broj investicijskih fondova $u$ afričkim zemljama. Ako se malo detaljnije analizira broj investicijskih fondova po pojedinim zemljama, može se zaključiti da razvijene zemlje imaju veći broj investicijskih fondova od zemalja u razvoju. Razlog tome je u razvijenosti nacionalnih ekonomija, višem bruto društvenom proizvodu i životnom standardu te razvijenosti financijskog sustava. Što je zemlja razvijenija, razvijeniji je i njezin financijski sustav odnosno postoji povezanost između razvijenosti nacionalne ekonomije i razvijenosti financijskog sustava. Na temelju ove konstatacije postavljena je hipoteza ovog rada kojom se nastoji dokazati postojanje značajne povezanosti između kretanja bruto društvenog proizvoda kao temeljnog indikatora razvijenosti zemlje i vrijednosti neto imovine investicijskih fondova. Ova hipoteza testirat će se na temelju podataka o kretanju bruto društvenog proizvoda $\mathrm{i}$ vrijednosti neto imovine investicijskih fondova u Republici Hrvatskoj.

\subsection{Sistematizacija prethodnih istraživanja o značajnosti i uspješnosti investicijskih fondova}

Velik broj autora provodio je istraživanje o značajnosti i uspješnosti investicijskih fondova kao i o identifikaciji značajnih faktora koji utječu na uspješnost investicijskih fondova. Recentna istraživanja vezana za investicijske fondove odnosila su se s jedne strane na njihovu uspješnost u vrijeme globalne financijske krize pri čemu su se ta istraživanja provodila u razvijenim zemljama, dok se druga istraživanja vezana za investicijske fondove odnose na istraživanje značajnosti i uspješnosti investicijskih fondova u tzv. tranzicijskim zemljama kao što su Poljska, Rumunjska Litva, Hrvatska, Srbija i Rusija. Također, nakon globalne financijske krize sve se više naglašava i istražuje koncept društveno odgovornog investicijskog fonda (Jones, Laan, Frost Loftus, 2007., str. 182.).

Jones, Laan, Frost i Loftus istraživali su uspješnost društveno odgovornih investicijskih fondova u Australiji u razdoblju od 1985. do 2005. godine. Rezultati njihovog istraživanja su pokazali da nema statistički značajne razlike u uspješnosti društveno odgovornih investicijskih fondova u odnosu na konvencionalne investicijske fondove (Jones, Laan, Frost Loftus, 2007., str. 182.). Ovi rezultati su u suprotnosti s rezultatima prethodnih istraživanja koja su pokazivala da postoje razlike u uspješnosti između društveno odgovornih i konvencionalnih investicijskih fondova (Jones, Laan, Frost Loftus, 2007., str. 182.).

Renneboog, Ter Horst, i Zhang istraživali su novčane tokove društveno odgovornih investicijskih fondova na svjetskoj razini te su utvrdili da su novčani tokovi društveno odgovornih investicijskih fondova manje osjetljiviji na prinose $u$ 
prošlim razdobljima u odnosu na konvencionalne fondove budući da su investitori u društveno odgovorne investicijske fondove više zainteresirani za etička i socijalna pitanja nego za uspješnost investicijskog fonda (Renneboog, Ter Horst, Zhang, 2011., str. 562.).

Becchetti, Ciciretti, Dalò i Herzel istraživali su uspješnost društveno odgovornih i konvencionalnih investicijskih fondova na različitim tržištima u razdoblju od 1992. do 2012. godine. Prema rezultatima njihovog istraživanja, društveno odgovorni investicijski fondovi su iskazali veću uspješnost u razdoblju nakon globalne financijske krize (2007. godina) u odnosu na konvencionalne investicijske fondove, dok to nije bio slučaj u razdoblju prije financijske krize. Također su utvrdili da ograničenja ulaganja i djelovanje na ograničenom tržišnom segmentu društveno odgovornim investicijskim fondovima ne predstavlja problem i ne ugrožava njihovu uspješnost (Becchetti, Ciciretti, Dalò i Herzel, 2015., str. 2560.).

Mietzner i Schweizer istraživali su sposobnost hedge fondova i privatnih dioničkih fondova za stvaranjem dodane vrijednosti za dioničare $\mathrm{i}$ investitore $\mathrm{u}$ Njemačkoj. Rezultati njihovog istraživanja su pokazali da se privatni dionički fondovi uspješniji u stvaranju vrijednosti za dioničare u odnosu na hedge fondove ponajviše zbog njihove dugoročne perspektive i veće sposobnosti prilagodbe sustavu korporativnog upravljanja (Mietzner i Schweizer, 2014., str. 181.).

Jarašius i Galinienè istraživali su utjecaj alternativnih investicijskih fondova na financijsku stabilnost $\mathrm{u}$ Litvi te su zaključili da su alternativni investicijski fondovi u Litvi uspješno osigurali svoj položaj na financijskom tržištu te da ne predstavljaju prijetnju financijskoj stabilnosti (Jarašius i Galinienė, 2014., str. 339.).

Mentel, Brozyna i Radwanski proveli su analizu učinkovitosti plasmana investicijskih fondova u Poljskoj u razdoblju financijske krize. Rezultati njihovog istraživanja nisu u potpunosti potvrdili hipotezu da je tijekom financijske krize uspješnost investicijskih fondova lošija u odnosu na razdoblje prije krize (Mentel, Brozyna i Radwanski, 2016., str. 98.). Mentel i Horváthová su identificirali značajne pravne, fiskalne, socio-ekeonomske faktore te učinkovitost investiranja u investicijske fondove u razdoblju od 1995. do 2015. u Euro zoni i u Poljskoj. Utvrdili su da problemi u Euro zoni i kontinuirani pad ratinga zemalja članica EU smanjuju povjerenje u tržište investicijskih fondova te da se tržište investicijskih fondova neće dalje razvijati bez stabilnog ekonomskog položaja i prosperiteta na tržištu kapitala. Mentel i Horváthová zaključuju da samo atraktivne stope povrata kao i povećano shvaćanje prednosti ulaganja u investicijske fondove mogu privući nove investitore (Mentel i Horváthová, 2016., str. 111.).

Vershinina, Goryinova, Zhdanova i Pavlovna Maksimova analizirale su mogućnost da se indikatori tržišta investicijskih fondova razmatraju kao indikator 
socio-ekonomskog razvoja zemlje na primjeru otvorenih investicijskih fondova $u$ Rusiji. U svom radu potvrdile su hipotezu da se sustav indikatora tržišta investicijskih fondova može smatrati kao indikator socio-ekonomskog razvoja zemlje. Također su predložile da sustav indikatora tržišta investicijskih fondova koji se može smatrati indikatorom socio-ekonomskog razvoja zemlje uključuje sljedeće pokazatelje: broj otvorenih investicijskih fondova, vrijednost neto imovine otvorenih investicijskih fondova te priljev i odljev kapitala iz otvorenih investicijskih fondova (Vershinina, Goryinova, Zhdanova i Pavlovna Maksimova, 2016., str. 2.).

Ionescu je istraživala industriju investicijskih fondova u Rumunjskoj te je zaključila da razvoj industrije investicijskih fondova u Rumunjskoj i dalje taje te da se investicijski fondovi smatraju rizičnima zahvaljujući nerazvijenom tržištu kapitala i needuciranim investitorima kao i vrlo popustljivoj regulativi investicijskih fondova u početnoj fazi. Utvrdila je da je u Rumunjskoj postignut značajan napredak u posljednjih desetak godina što se tiče razvoja industrije investicijskih fondova, ali i da je financijska kriza ostavila značajan učinak na tržište kapitala te razotkrila negativne učinke sistemskog rizika (Ionescu, str. 90.)

Barjaktarović, Ječmenica i Paunović proveli su analizu poslovanja otvorenih investicijskih fondova u Srbiji u razdoblju od 2007. do 2012. godine. Primjenom Jensenove alphe, Sharperovog i Sortinovog pokazatelja utvrdili su da u promatranom razdoblju uspješnost otvorenih investicijskih fondova u Srbiji nije na zadovoljavajućoj razini (Barjaktarović, Ječmenica i Paunović, 2013., str. 79.).

Ćurković i Krišto analizirali su uspješnost poslovanja otvorenih investicijskih fondova s javnom ponudom (UCITS) u Hrvatskoj u razdoblju od početka 2011. godine do kraja 2014. godine. Temeljem provedene analize zaključili su da su fondovi s višom vrijednosti neto imovine bili uspješniji u odnosu na fondove $\mathrm{s}$ ispodprosječnom vrijednosti neto imovine. Fondovi s ispodprosječnom vrijednosti neto imovine su bili volatilniji u odnosu na fondove s višom vrijednosti neto imovine. Također, u radu su konstatirali da su fondovi kojima upravljaju društva za upravljanje u stranom vlasništvu uspješniji u odnosu na fondove kojima upravljaju društva za upravljanje u domaćem vlasništvu (Ćurković i Krišto, 2017., str. 11.).

\subsection{Značajnost investicijskih fondova u Republici Hrvatskoj}

Aktualni regulatorni okvir investicijskih fondova u Republici Hrvatskoj dozvoljava osnivanje i djelovanja otvorenih i zatvorenih investicijskih fondova. Razvoj investicijskih fondova u Republici Hrvatskoj započeo je početkom 90tih godina 20. stoljeća kada su se osnovali tzv. privatizacijski investicijski fondovi koji su 
bili ključni čimbenik privatizacijskog procesa. Osnovni cilj privatizacijskih investicijskih fondova sastojao se u omogućavanju transformacije postsocijalističkih državnih poduzeća u privatna poduzeća i u moderne korporacije. Nakon završetka privatizacijskog procesa, broj investicijskih fondova u Republici Hrvatskoj se postupno povećavao kako se postupno razvijalo tržište kapitala. Porast broja investicijskih fondova potaknuo je potrebu razvoja jače i konkretnije regulative investicijskih fondova. U skladu s tim, 2005. godine osniva se Hrvatska agencija za nadzor financijskih usluga (HANFA) kao nacionalni regulator za nadzor financijskih tržišta, financijskih usluga i institucija koje pružaju financijske usluge. HANFA je, između ostalog, odgovorna za nadzor investicijskih fondova i društava za upravljanje investicijskim fondovima u Republici Hrvatskoj.

Trenutno, u Republici Hrvatskoj postoji 131 investicijski fond, od čega su 3 zatvorena investicijska fonda, a 128 je otvorenih investicijskih fondova. Samo je jedan investicijski fond specijaliziran za ulaganje u nekretnine, dok su svi ostali specijalizirani za ulaganje u financijske instrumente. Kretanje broja investicijskih fondova u Republici Hrvatskoj u razdoblju od 2014. do 31.5.2017. godine prikazan je na slici 4 .

Slika 4. Kretanje broja investicijskih fondova u Republici Hrvatskoj u razdoblju od 31.1.2014. do 31.5.2017.

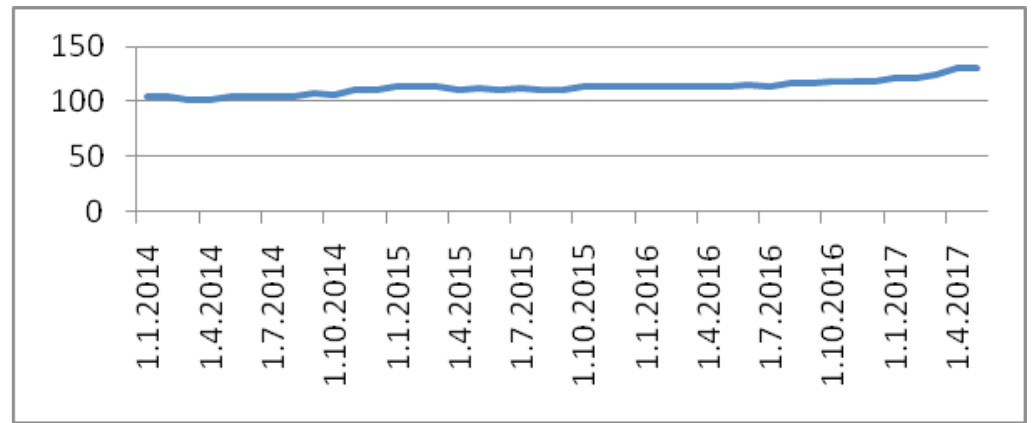

Izvor: obrada autora prema HANFA, Broj investicijskih fondova, dostupno na http:// www.hanfa.hr/publikacije/statistika/\#section3 (pristupljeno 30.6.2017.)

Investicijski fondovi na današnjem tržištu kapitala u Republici Hrvatskoj djeluju kao tipični financijski posrednici. Iako njihova uloga i značajnost nije izražena u tolikoj mjeri kao kod zemalja s razvijenim tržištem kapitala, investicijski fondovi postupno zauzimaju sve značajniju ulogu na hrvatskom tržištu kapitala kao izuzetno pogodan i prihvatljiv oblik investiranja novčanih sredstava novčano suficitarnih subjekata. Značajnost investicijskih fondova kao investicijske mogućnosti znatno je porasla nakon recentnih pada kamatnih stopa na štedne uloge i depozite u kreditnim institucijama u Republici Hrvatskoj. Upravo taj pad kamatnih stopa 
na štedne uloge i depozite potaknuo je velik broj štediša i investitora na ulaganja $\mathrm{u}$ investicijske fondove. Rastu značajnosti investicijskih fondova pridonosi i postojanje različitih tipova investicijskih fondova koji se prilagođavaju različitim tipovima investitora.

Prema postojećem regulatornom okviru investicijskih fondova u Republici $\mathrm{Hr}$ vatskoj, dvije su osnovne vrste investicijskih fondova, a to su: otvoreni investicijski fondovi s javnom ponudom (UCITS fondovi) i alternativni investicijski fondovi (AIF). „UCITS fond je otvoreni investicijski fond s javnom ponudom koji osniva društvo za upravljanje UCITS fondovima te, poštujući načela razdiobe rizika, ulaže zajedničku imovinu ulagatelja, prikupljenu javnom ponudom udjela u UCITS fondu, u likvidnu financijsku imovinu u skladu s odredbama Zakona o otvorenim investicijskim fondovima s javnom ponudom, prospekta i pravila toga fonda. Udjeli u UCITS fondu se na zahtjev ulagatelja otkupljuju iz imovine toga fonda" (HANFA). Ova vrsta investicijskih fondova pogodna je i prilagođena je tzv. malim investitorima koji nemaju relevantna znanja o investicijskoj analizi te tržištu kapitala i koji uobičajeno raspolažu s malim iznosom ulaganja. „Alternativni investicijski fond (AIF) je investicijski fond koji osniva društvo za upravljanje alternativnim investicijskim fondovima (UAIF), sa svrhom prikupljanja sredstava javnom ili privatnom ponudom te ulaganja tih sredstava u različite vrste imovine, u skladu s odredbama Zakona o alternativnim investicijskim fondovima te unaprijed određenom strategijom i ciljem ulaganja AIF-a, isključivo u korist imatelja udjela tog AIF-a. AIF može biti otvoreni i zatvoreni" (HANFA). Zatvoreni investicijski fondovi mogu biti osnovani ili kao dionička društva ili kao društva s ograničenom odgovornosti. Alternativni investicijski fondovi su usmjereni na kvalificirane i profesionalne investitore koji raspolažu s velikim iznosima ulaganja te koji imaju adekvatna znanja iz područja investicijske analize i tržišta kapitala (Perčević, Mićin, 2017.)

I UCITS fondovi i alternativni investicijski fondovi su uglavnom usmjereni na ulaganja u različite vrste financijskih instrumenata. Samo je jedan zatvoreni alternativni investicijski fond specijaliziran za ulaganje u nekretnine. U skladu s navedenim, vrijednost neto imovine investicijskih fondova u Republici Hrvatskoj ovisi o tržišnim cijenama financijskih instrumenata. Kretanje vrijednosti neto imovine investicijskih fondova u Republici Hrvatskoj u razdoblju od početka 2013. do sredine 2016. godine prikazano je na sljedećoj slici. 
Slika 5. Kretanje vrijednosti neto imovine investicijskih fondova u Republici Hrvatskoj u razdoblju od početka 2013. do sredine 2016. u tisućama HRK

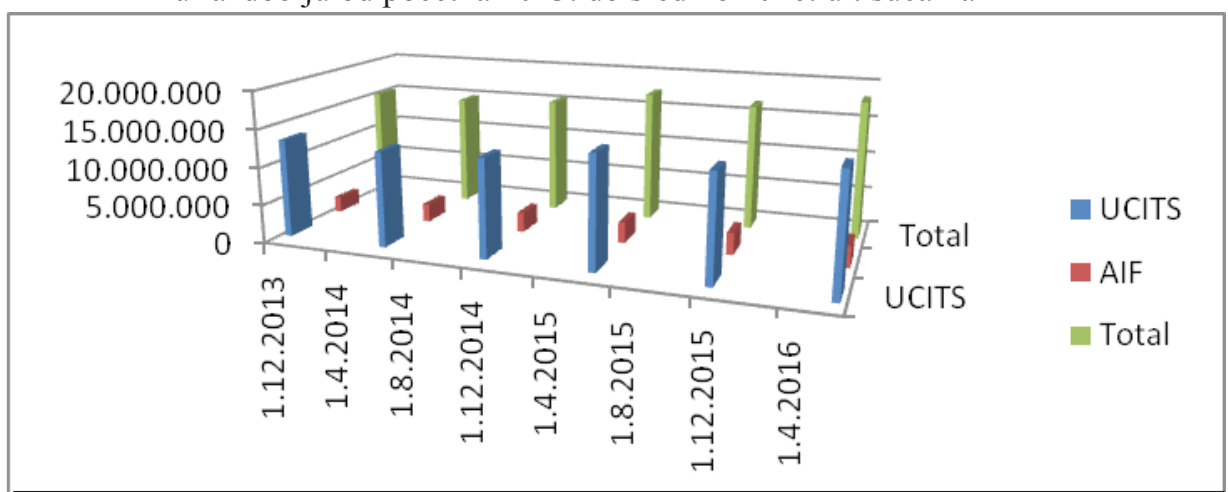

Izvor: obrada autora prema HANFA, Neto imovina investicijskih fondova,dostupno na http://www.hanfa.hr/publikacije/statistika/\#section3 (pristupljeno 30.6.2017.)

Kao što se može vidjeti na prethodnoj slici, vrijednost neto imovine investicijskih fondova u Republici Hrvatskoj u promatranom razdoblju pokazuje trend rasta što je i jedan od indikatora porasta interesa investitora u Hrvatskoj za ulaganje $\mathrm{u}$ investicijske fondove. Iako vrijednost neto imovine investicijskih fondova ovisi ponajprije o tržišnim cijenama financijskih instrumenata, značajan utjecaj zasigurno ima i stupanj razvoja nacionalne ekonomije koji se uobičajeno mjeri putem bruto domaćeg proizvoda zemlje. U skladu s tim u ovom radu istražuje se povezanost između razvoja nacionalne ekonomije koji se mjeri iznosom bruto domaćeg proizvoda i vrijednosti neto imovine investicijskih fondova na primjeru Republike Hrvatske.

Tablica 2. Struktura ulaganja UCITS fondova - ukupna imovina (u tisućama kuna)

\begin{tabular}{|c|c|c|c|c|c|}
\hline Vrsta imovine & 31.1 .2014 & 31.12 .2014 & 31.12 .2015 & 31.12 .2016 & 30.6 .2017 \\
\hline Novčana sredstva & 1.807 .988 & 952.285 & 1.008 .191 & 2.410 .810 & 2.383 .949 \\
\hline Potraživanja & 252.529 & 131.009 & 140.314 & 326.203 & 269.590 \\
\hline $\begin{array}{c}\text { Vrijednosni papiri } \\
\text { i depoziti }\end{array}$ & 11.925 .846 & 12.174 .327 & 12.942 .475 & 17.158 .828 & 16.149 .249 \\
\hline Domaći & 10.362 .381 & 10.675 .492 & 11.443 .852 & 15.580 .920 & 14.319 .225 \\
\hline Inozemni & 1.563 .465 & 1.498 .835 & 1.498 .623 & 1.577 .908 & 1.830 .024 \\
\hline Ostala imovina & 0 & 5.020 & 7.560 & 12.200 & 14.290 \\
\hline $\begin{array}{c}\text { UKUPNA IMO- } \\
\text { VINA }\end{array}$ & 13.986 .363 & 13.262 .641 & 14.098 .540 & 19.908 .041 & 18.817 .077 \\
\hline
\end{tabular}

Izvor: obrada autora prema http://www.hanfa.hr/publikacije/statistika/

(pristupljeno: 5. 8. 2017.) 
S obzirom na to neto imovina UCITS fondova čini najveći dio ukupne neto imovine investicijskih fondova u Republici Hrvatskoj, istražena je njihova struktura ulaganja, odnosno od čega se sastoji njihova ukupna imovina za razdoblje od 31. 1. 2014. do 30. 6. 2017. Prema dostupnim podacima, može se zaključiti da UCITS fondovi u Republici Hrvatskoj najviše ulažu u vrijednosne papire i depozite, odnosno na vrijednosne papire i depozite se odnosi otprilike $85 \%$ do $92 \%$ ukupne imovine. S obzirom da vrijednosni papiri i depoziti čine najveći dio ukupne imovine, istražena je njihova struktura.

Slika 6. Struktura vrijednosnih papira i depozita kao dijela strukture ulaganja UCITS fondova (u tisućama kuna)

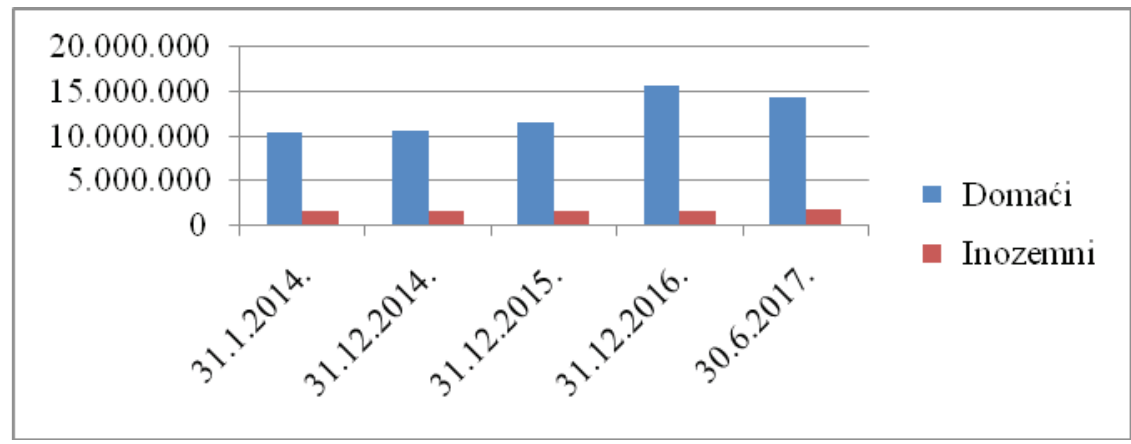

Izvor: obrada autora prema http://www.hanfa.hr/publikacije/statistika/ (pristupljeno: 5. 8. 2017.)

Kao što se može uočiti na slici 6, u razdoblju od 31.1.2014. do 30.6.2017., UCITS fondovi su značajno više ulagali u domaće vrijednosne papire i depozite. Drugim riječima, ukoliko UCITS fondovi čija neto imovina predstavlja najveći dio neto imovine investicijskih fondova u Republici Hrvatskoj ulažu većinom u domaće vrijednosne papire i depozite, tada i ukupna vrijednost neto imovine investicijskih fondova u Republici Hrvatskoj ovisi o gospodarskoj situaciji u zemlji. 
Tablica 3. Struktura vrijednosnih papira i depozita kao dijela strukture ulaganja UCITS fondova (u tisućama kuna)

\begin{tabular}{|c|c|c|c|c|c|}
\hline \multicolumn{1}{|c|}{ Vrsta imovine } & 31.1 .2014 & 31.12 .2014 & 31.12 .2015 & 31.12 .2016 & 30.6 .2017 \\
\hline $\begin{array}{l}\text { Vrijednosni papiri i } \\
\text { depoziti }\end{array}$ & 11.925 .846 & 12.174 .327 & 12.942 .475 & 17.158 .828 & 16.149 .249 \\
\hline Domaći & 10.362 .381 & 10.675 .492 & 11.443 .852 & 15.580 .920 & 14.319 .225 \\
\hline Dionice + GDR & 712.717 & 673.013 & 670.088 & 826.260 & 681.918 \\
\hline Državne obveznice & 671.768 & 1.941 .297 & 2.583 .365 & 5.652 .130 & 5.173 .412 \\
\hline $\begin{array}{l}\text { Municipalne } \\
\text { obveznice }\end{array}$ & 1.621 & 1.234 & 820 & 404 & 303 \\
\hline $\begin{array}{l}\text { Korporativne } \\
\text { obveznice }\end{array}$ & 236.273 & 223.177 & 234.049 & 276.093 & 231.585 \\
\hline AIF & 0 & 0 & 0 & 0 & 0 \\
\hline UCITS fondovi & 119.930 & 89.595 & 93.997 & 86.445 & 151.761 \\
\hline $\begin{array}{l}\text { Instrumenti tržišta } \\
\text { novca }\end{array}$ & 3.801 .545 & 4.014 .022 & 3.408 .919 & 4.830 .844 & 4.991 .852 \\
\hline Depoziti & 4.818 .527 & 3.733 .155 & 4.452 .613 & 3.908 .746 & 3.088 .394 \\
\hline Inozemni & 1.563 .465 & 1.498 .835 & 1.498 .623 & 1.577 .908 & 1.830 .024 \\
\hline Dionice & 1.160 .507 & 1.081 .684 & 1.058 .361 & 1.023 .485 & 1.217 .153 \\
\hline Državne obveznice & 91.211 & 136.001 & 89.913 & 224.790 & 202.766 \\
\hline $\begin{array}{l}\text { Municipalne } \\
\text { obveznice }\end{array}$ & 0 & 0 & 0 & 0 & 0 \\
\hline $\begin{array}{l}\text { Korporativne } \\
\text { obveznice }\end{array}$ & 127.117 & 69.225 & 59.294 & 37.305 & 50.748 \\
\hline AIF & 126 & 0 & 1.734 & 0 & 0 \\
\hline $\begin{array}{l}\text { UCITS fondovi i OIF s } \\
\text { javnom ponudom }\end{array}$ & 184.503 & 198.517 & 289.321 & 292.328 & 336.916 \\
\hline $\begin{array}{l}\text { Instrumenti tržišta } \\
\text { novca }\end{array}$ & 0 & 13.409 & 0 & 0 & 22.440 \\
\hline Depoziti & 0 & 0 & 0 & 0 \\
\hline
\end{tabular}

Izvor: obrada autora prema http://www.hanfa.hr/publikacije/statistika/ (pristupljeno: 5. 8. 2017.)

Na temelju tablice 3 može se zaključiti da s aspekta domaćih vrijednosnih papira, poduzeća najviše ulažu u instrumente tržišta novca, depozite te $u$ državne obveznice. Može se primijetiti porast udjela državnih obveznica u promatranom razdoblju. Što se tiče ulaganja u inozemne vrijednosne papire i depozite, većinom se radi o ulaganju u dionice. Međutim, iako se više ulaže u inozemne dionice nego u domaće dionice, i dalje ulaganja u inozemne dionice čine manji dio strukture ulaganja UCITS fondova $\mathrm{u}$ vrijednosne papire $\mathrm{u}$ odnosu na domaće vrijednosne papire i depozite. 


\section{METODOLOGIJA I REZULTATI ISTRAŽIVANJA}

\subsection{Metodologija istraživanja povezanosti neto imovine investicijskih fondova i bruto domaćeg proizvoda}

Kao što je već prethodno spomenuto, u ovom radu će se analizirati povezanost kretanja neto imovine investicijskih fondova u Republici Hrvatskoj i bruto domaćeg proizvoda (u nastavku: BDP). S obzirom na to da je BDP pokazatelj ekonomske aktivnosti neke zemlje, odnosno pokazatelj rasta gospodarstva neke zemlje, pretpostavlja se da će pozitivna ekonomska kretanja pozitivno utjecati na rast tržišnih cijena vrijednosnih papira što će posljedično utjecati na rast neto imovine investicijskih fondova. Prema tome, može se postaviti hipoteza: Postoji pozitivna povezanost između kretanja neto imovine investicijskih fondova u Republici Hrvatskoj i bruto domaćeg proizvoda.

Kako bi se potvrdila ili odbacila hipoteza, istraživati će se povezanost spomenutih varijabli za razdoblje od 2006. do 2016. godine, tj. promatrano razdoblje uključuje 11 godina. Pri tome će se kao varijabla neto imovina investicijskih fondova promatrati vrijednost neto imovine investicijskih fondova s javnom ponudom u Republici Hrvatskoj na dan 31.12., odnosno na kraju obračunskog razdoblja. Podaci o kretanju BDP-a će se promatrati na godišnjoj razini, odnosno, koliki je BDP u svakoj godini u razdoblju od 2006. do 2016. godine. Podaci o kretanjima neto imovine investicijskih fondova su preuzeti s web stranice Hrvatske agencije za nadzor financijskih usluga (http://www.hanfa.hr/publikacije/statistika/), dok su podaci o iznosu BDP-a dostupni na web stranicama Državnog zavoda za statistiku Republike Hrvatske u okviru izdanih publikacija (http://www.dzs.hr/).

Važno je naglasiti da je kao neto imovina investicijskih fondova uzeta u obzir neto imovina investicijskih fondova s javnom ponudom iz razloga kako bi podaci mogli biti unificirani za cijelo promatrano razdoblje. Prema tome, istraživana je povezanost neto imovine otvorenih investicijskih fondova s javnom ponudom (to su inače UCITS fondovi), zatvorenih investicijskih fondova s javnom ponudom i ukupna vrijednost neto imovine investicijskih fondova s javnom ponudom što je zbroj gornje navedenih. Podaci o BDP-u su preuzeti iz publikacije Državnog zavoda za statistiku Republike Hrvatske na godišnjoj razini, pri čemu je analiziran BDP u tekućim cijenama. U spomenutoj publikaciji je dan i iznos BDP-a koji se odnosi na financijske djelatnosti i djelatnosti osiguranja pa je i ta vrijednost stavljena u odnos s neto imovinom investicijskih fondova u kasnijoj analizi. 


\subsection{Rezultati istraživanja povezanosti neto imovine investicijskih fondova i bruto domaćeg proizvoda}

Na slikama 7. i 8. dan je grafički prikaz kretanja neto imovine investicijskih fondova u Republici Hrvatskoj u razdoblju od 2006. do 2016. godine, kao i kretanje bruto domaćeg proizvoda u financijskim djelatnostima i djelatnosti osiguranja, ali i ukupno.

Slika 7. Neto imovina investicijskih fondova s javnom ponudom u Republici Hrvatskoj

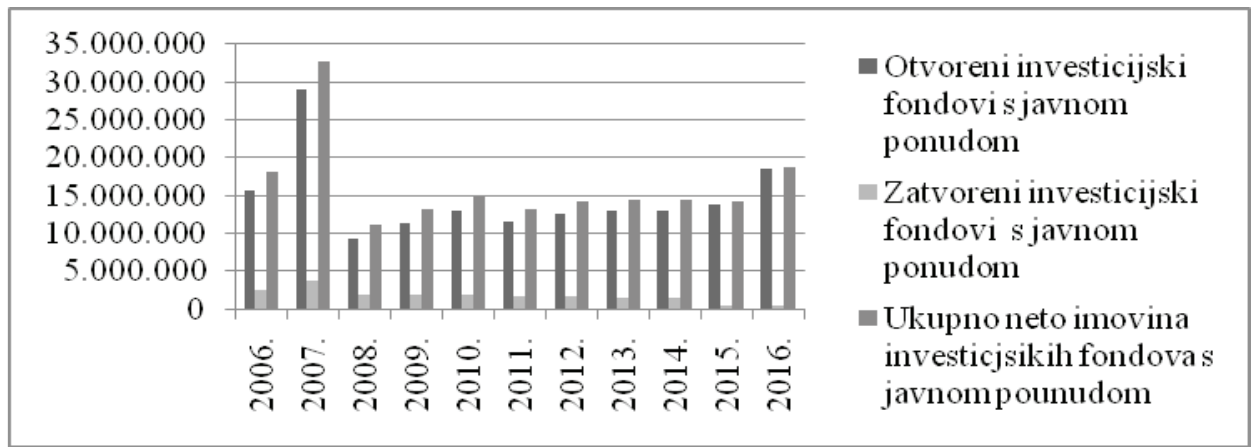

Izvor: obrada autora prema podacima dostupnima na: http://www.hanfa.hr/publikacije/ statistika/\#section3

Prema slici 7, može se uočiti da ukupna neto imovina investicijskih fondova s javnom ponudom raste u razdoblju od 2008. godine, kad je naglo pala u odnosu na 2007. godinu, što je ujedno godina koja označava financijsku krizu. Dakle, ukupna vrijednost neto imovine investicijskih fondova pala je u 2008. godini, što može biti odraz financijske krize, međutim, od onda je u porastu. Većim dijelom se ta vrijednost neto imovine odnosi na neto imovinu otvorenih investicijskih fondova s javnom ponudom, odnosno neto imovinu UCITS fondova.

Slika 8. Bruto domaći proizvod u tržišnim cijenama u razdoblju u Republici Hrvatskoj

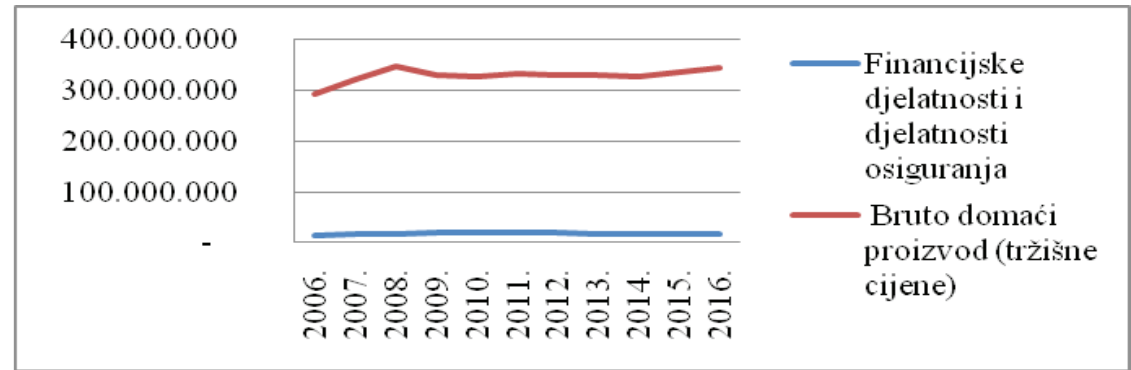

Izvor: obrada autora prema podacima dostupnima na: http://www.dzs.hr/ 
BDP u tekućim cijenama je u porastu od 2014. do 2016. godine, dok u prethodnim razdobljima bilježi lagan pad. Međutim, razlika u BDP-u u zadnjih 10 godina nije značajna, osim u razdoblju od 2008. do 2009. godine kada se može zaključiti da je bio malo veći pad.

Iz prethodne dvije slike se može zaključiti da i vrijednost neto imovine investicijskih fondova raste zadnjih par godina, kao i BDP. Međutim, razdoblje od 2007. do 2008. godine označava značajne promjene u vrijednostima tih varijabli kada je financijska kriza utjecala na njihov pad. Međutim, iako je došlo do oporavka vrijednosti neto imovine investicijskih fondova, kao i rasta BDP-a, na temelju ovih dviju slika ne može se precizno zaključiti da su u svim godinama jednake promjene vrijednosti odnosno da je tržište kapitala u svi godinama jednako reagirale na ekonomsku situaciju u državi kao i pokazatelj gospodarskog rasta, odnosno BDP.

Tablica 4. Korelacija između neto imovine investicijskih fondova i BDP-a u Republici Hrvatskoj

\begin{tabular}{|l|c|c|c|c|c|}
\hline & $\begin{array}{c}\text { Otvoreni } \\
\text { investicijski } \\
\text { fondovi s } \\
\text { javnom ponu- } \\
\text { dom }\end{array}$ & $\begin{array}{c}\text { Zatvoreni } \\
\text { investicijski } \\
\text { fondovi s } \\
\text { javnom ponu- } \\
\text { dom }\end{array}$ & $\begin{array}{c}\text { Ukupno neto } \\
\text { imovina inve- } \\
\text { sticijskih fon- } \\
\text { dova s javnom } \\
\text { ponudom }\end{array}$ & $\begin{array}{c}\text { Financijske } \\
\text { djelatnosti } \\
\text { i djelatnosti } \\
\text { osiguranja }\end{array}$ & $\begin{array}{c}\text { Bruto } \\
\text { domaći } \\
\text { proi- } \\
\text { zvod } \\
\text { (tržišne } \\
\text { cijene) }\end{array}$ \\
\hline $\begin{array}{l}\text { Otvoreni inve- } \\
\text { sticijski fondovi } \\
\text { s javnom ponu- } \\
\text { dom }\end{array}$ & 1 & 1 & & & \\
\hline $\begin{array}{l}\text { Zatvoreni inve- } \\
\text { sticijski fondovi } \\
\text { s javnom ponu- } \\
\text { dom }\end{array}$ & 0,502012531 & 0,61434481 & 1 & & \\
\hline $\begin{array}{l}\text { Ukupno neto } \\
\text { imovina investi- } \\
\text { cijskih fondova } \\
\text { s javnom ponu- } \\
\text { dom }\end{array}$ & 0,990816191 & $-0,523262063$ & $-0,323360862$ & 0,735618413 & 1 \\
\hline $\begin{array}{l}\text { Financijske dje- } \\
\text { latnosti i djelat- } \\
\text { nosti osiguranja }\end{array}$ & $-0,493156595$ & $-0,387731369$ & $-0,510540795$ & & \\
\hline $\begin{array}{l}\text { Bruto domaći } \\
\text { proizvod }\end{array}$ & $-0,264763986$ & $-0,53$ & & \\
\hline
\end{tabular}

Izvor: obrada autora

Prema tablici 4 može se zaključiti da vrijednosti neto imovine otvorenih investicijskih fondova s javnom ponudom, zatvorenih investicijskih fondova s javnom 
ponudom, kao i njihova ukupna vrijednost negativno koreliraju s pokazateljem BDP, ukupnim i onim za financijske djelatnosti i djelatnosti osiguranja. S obzirom na vrijednosti koeficijenata korelacije, ta korelacija je slaba do umjerena. Prema tome se ne može zaključiti da su kretanja neto imovine investicijskih fondova s javnom ponudom pozitivno statistički povezana s BDP-om.

Iz sveg navedenog se može zaključiti da iako vrijednosti neto imovine investicijskih fondova zadnjih godina rastu, kao i BDP, oni ne rastu istim intenzitetom, odnosno, ne postoji jaka pozitivna povezanost između tih varijabli.

\section{ZAKLJUČAK}

Broj investicijskih fondova u Republici Hrvatskoj raste, što pokazuje da investicijski fondovi postaju sve značajniji sudionik na tržištu kapitala. Odnosno, sve više investitora investira višak svojih novčanih sredstva $u$ investicijske fondove, disperzirajući rizik ulaganja prenošenjem novčanih sredstava onome tko ima znanje, stručnost i raspolaže informacijama. S obzirom na to da BDP pokazuje kakva je gospodarska situacija u nekoj zemlji, očekuje se da ukoliko BDP raste, rastu i cijene vrijednosnih papira na tržištu kapitala, a samim time i vrijednosti neto imovine investicijskih fondova. Stoga je u ovom radu polazište pretpostavka da su vrijednost neto imovine investicijskih fondova i BDP pozitivno povezani, odnosno, da se te dvije varijable kreću u istom smjeru. Neto imovina investicijskih fondova raste, nakon značajnog pada u 2008. godini. Isto tako, raste i BDP koji pokazuje kakva je ekonomska aktivnost neke zemlje. Važno je naglasiti da se ukupna neto imovina investicijskih fondova većinom odnosi na UCITS fondove, odnosno otvorene investicijske fondova s javnom ponudom koji primarno ulažu u domaće vrijednosne papire i depozite. Postavljena hipoteza da su neto imovina investicijskih fondova i BDP statistički pozitivno povezana je odbačena. Rezultati istraživanja su pokazali da je povezanost između neto imovine investicijskih fondova s javnom ponudom slaba i negativna. Razloge slabe negativne povezanosti je moguće objasniti time da, iako obje varijable općenito rastu u periodu od 2008., bilo je manjih oscilacija u vrijednosti neto imovine investicijskih fondova, kao i u rastu BDP-a koje se nisu poklapale u određenim razdobljima. 


\section{LITERATURA}

1. Barjaktarović, L., Ječmenica, D., Paunović, M. (2013.): Ratio Analysis of Actual Business Performance of Open Investment Funds in Serbia, Serbian Journal of Management 8 (1) pp. 79-93.

2. Beccheti, L., Ciciretti, R., Dalò. A., Herzel, S.: (2015.) Socially responsible and conventional investment funds: performance comparison and the global, Applied Economics, 47:25, pp. 2541-2562., DOI: 10.1080/00036846.2014.1000517

3. Brealey, R. A., Myers, S. C., Marcus, A. J. (2004.): Fundamantals of Corporate Finance, New York, McGraw Hill Irwin

4. Ćurković, M., Krišto, J. (2017.): Performance Measurement of UCITS Investment Funds in Croatia., Special issue, UTMS Journal of Economics 8 (1), pp. 11-18.

5. Gulin, D. (2001.): Računovodstveno praćenje aktivnosti investicijskih fondova s naglaskom na privatizacijskim investicijskim fondovima, Zbornik radova, Revicon, Neum - Sarajevo, pp. 155-178.

6. HANFA, Broj investicijskih fondova, Neto imovina investicijskih fondova, http://www.hanfa.hr/HR/nav/106/statistika.html\#section3 (pristupljeno 30.6.2017.)

7. HANFA,http://www.hanfa.hr/registar/23/aif?page=1i http://www.hanfa.hr/ registar/22/ (pristupljeno 30.6.2017.)

8. Investment Company Fact Book 2014., dostupno na: https://www.quora. $\mathrm{com} /$ What-is-the-total-number-of-mutual-funds-in-the-US, pristupljeno 28.06.2017.

9. Ionescu, A. Investment Fund Industry in Romania, "Nicolae Titulescu" University, Bucharest, Romania, pp. 90-96.

10. Jarašius, G., Galinienè, B. (2014.): Alternative Investment Funds Implications for Financial Stability in Lithuania, Business: Theory and Practice. 15(4), pp. 339-350 DOI 10.3846/btp.2014.473

11. Jones, S., Van der Laan, S., Frost, G., Loftus, J. (2008.): The Investment Performance of Socially Responsible Investment Funds in Australia, Journal of Business Ethics (2008.) 80, pp. 181-20.3, DOI 10.1007/s10551-007-9412-6

12. Mentel, G., Brozyna, J., Radwanski, R. (2016.): Assesment of the Effectiveness of Investment Funds Placement in Poland in the Times of Crisis, Actual Problems of Economics, vol. 6 (180), pp. 91-101.

13. Mentel, G., Horváthová, Z. (2016.), Factors of Efficiency of Open Investment Funds in 1997-2015., Economics and Sociology, Vol. 9, No 1, pp. 101-113. DOI: 10.14254/2071-789X.2016/9-1/7 
14. Mietzner, M., Schweizer. D. (2014.): Hedge funds versus private equity funds as shareholder activists in Germany-differences in value creation, J Econ Finan (2014.) 38, pp. 181-208.

15. MSI Bruto domaći proizvod; Publikacija Državnog zavoda za statistiku Republike Hrvatske (www.dzs.hr.)

16. Perčević, H., Hladika, M., Mićin, M. (2016): The Interdependence between the Market Price of the Share and Earnings per Share of Closed-Ended Investment Funds in Croatia, Zbornik radova 5. Međunarodnog znanstvenog simpozija "Gospodarstvo Istočne Hrvatske - vizija i razvoj”, Sveučilište Josipa Jurja Strossmayera u Osijeku ; Ekonomski fakultet u Osijeku, Osijek, pp. 1069-1077.

17. Perčević, H., Mićin, M. (2017.): Is There a Connection Between Investment Funds' Net Assets and Stock Indices? - Evidence from the Croatian Capital Market, Proceedinngs of the International Multidisciplinary Scientific Conference „Multiscience - XXXI. microCad, University of Miskolc

18. Pilbeam, K. (2005.): Finance and Financial Markets, Hampshire and New York, Palgrave Macmillan

19. Pravilnik o utvrđivanju neto vrijednosti imovine UCITS fonda i cijene udjela u UCITS fondu (NN, br. 69/16) : http://narodne-novine.nn.hr/clanci/sluzbeni/2016_07_69_1657.html (pristupljeno 30.6.2017.)

20. Pravilnik o utvrđivanju neto vrijednosti imovine AIF-a i cijene udjela AIF-a: http://narodne-novine.nn.hr/clanci/sluzbeni/2016_07_69_1657.html (pristupljeno 30.6.2017.)

21. Renneboog, L., Ter Horst, J., Zhang, C. (2011.): Is ethical money financially smart? Nonfinancial attributes and money flows of socially responsible investment funds, Journal of Financial Intermediation, vol. 20, issue 4, Academic Press Inc. Elsevier Science, Elsevier BV, Elsevier, San Diego, pp. 562-588.

22. Vershinina, A. A., Goryinova, L. V., Zhdanova,O. A., Pavlovna Maksimova, T. (2016.): State of the Investment Fund Market of as an Indicator of the Country's Socio-Economic Development, Journal of Internet Banking and Commerce, vol. 21, no. S3, Special Issue: Finance, Services Sector and Commerce: Innovations and Investments, Edited By: Mikhail N. Dudin 
Hrvoje Perčević, Ph.D.

Faculty of Economics and Business, University of Zagreb, Zagreb, Republic of Croatia

hpercevic@efzg.hr

Marina Mićin, M.Sc.

Faculty of Economics and Business, University of Zagreb, Zagreb, Republic of Croatia

mmicin@efzg.hr

\title{
THE INTERDEPENDANCE BETWEEN THE MOVEMENT OF NET ASSETS OF INVESTMENT FUNDS AND GROSS DOMESTIC PRODUCT IN THE REPUBLIC OF CROATIA
}

Review

\begin{abstract}
Investment funds are becoming more and more important participants on the capital market in the Republic of Croatia, ie investors increasingly use investment funds as one of the possibilities for investing liquid funds. The basic objective of investing in shares and units of investment funds is to achieve satisfactory return on invested funds with respect to the anticipated investment risk. Investing in shares and units of investment funds represents an interesting form of investment, especially the so-called small investors, since a large number of so-called small investors does not have enough relevant knowledge and experience in the area of investment analysis and the capital market and therefore they can not form an investment portfolio that will disperse the risk of investment. Since the investment fund managers form a portfolio of securities based on the diversification principle, small investors indirectly disperse the investment risk by investing in shares and units of investment funds,. Therefore, small investors who potentially have lack of knowledge and experience to access the capital market themselves, are enabled to participate in the capital market over those who have the knowledge and opportunities. The price of unit in the fund, ie, the net asset value of the fund is calculated on a daily basis and it depends on the movements in the price of securities included in the portfolio of the fund. Capital stock market prices are linked to the gross domestic product (GDP), ie when the economic situation in the country is favorable, GDP rises as well as stock prices. In other words, the growth of a country's economy affects GDP growth, as well as the growth in market prices of securities. The increase in market prices of securities consequently affects the growth of net assets of investment funds, and vice versa. The
\end{abstract}


basic objective of this paper is to investigate whether the movement of net assets of investment funds is consistent with the movements of GDP, ie whether there is a correlation between these two variables. The paper analyzes trends in the value of net assets of investment funds and GDP in the Republic of Croatia.

Keywords: investment funds, net assets, gross domestic product, Republic of Croatia

JEL: M41 